\title{
Mitologia: abordagem metodológica para o Historiador da Antigüidade Clássica
}

Andrea Lúcia Dorini de Oliveira Carvalho Rossi*

Resumo: $O$ tema central deste artigo é a aplicação da análise semiótica como metodologia de análise histórica do mito presente nos Discursos de Dion Crisóstomo, filósofo bitiniano que viveu entre 40 e 115 d.C. sob o Império Romano.

Palavras-chave: Mito, Império Romano, Dion Crisóstomo.

Ao abordar a temática do mito na Antigüidade Clássica, é certo que se evoca uma questão complexa e que, por isso, apenas serão indicados alguns caminhos que podem ser seguidos. Antes de começar uma discussão sobre o mito na Antigüidade, deve-se pensar em que se constitui o mito. Adotando o mito como uma fala, uma narrativa, infere-se que a linguagem é o veículo do mito.

Segundo Everardo Rocha,

[s]e o mito fosse uma narrativa ou uma fala qualquer, estaria diluído completamente. O mito é, então, uma narrativa especial, particular, capaz de ser distinguida das demais narrativas humanas.

Conceituar mito, portanto, é uma tarefa difícil, que está subordinada às mais diferentes correntes do pensamento humano. O mito será entendido aqui no seu aspecto pragmático, isto é, na sua função. Assim, a interpretação do mito está na razão direta de como ele atua na sociedade e, por isso, a interpretação é variável. Segundo Mircea Eliade, ${ }^{1}$ "O mito é uma realidade cultural extremamente complexa, que pode ser abordada e interpretada através de perspectivas múltiplas e complementares".

Werner Jaeger aborda o mito como forma excepcional:

Falamos do valor educativo dos exemplos criados pelo mito ... O mito contém em si este significado normativo, mesmo quando não é empregado expressamente como modelo ou 
exemplo ... O mito serve sempre de instância normativa para a qual apela o orador. Há no seu âmago alguma coisa que tem validade universal. Não têm um caráter meramente fictício, embora originariamente seja, sem dúvida alguma, o sedimento de acontecimentos históricos que alcançaram a imortalidade através de uma longa tradição e da interpretação enaltecedora da fantasia criadora da posteridade.

Desse modo, para discutir o mito como expressão do pensamento dos homens, as idéias propostas por Jaeger serão levadas em conta com mais atenção. O mito será entendido como sendo a narrativa daquilo que se pretende que seja, enquanto expressão do pensamento de uma dada sociedade.

Roland Barthes propõe igualmente o modelo de mito, segundo o qual,

... o mito é um sistema de comunicação, é uma mensagem. Eis por que não poderia ser um objeto, um conceito, ou uma idéia: ele é um modo de significação, uma forma ... já que o mito é uma fala, tudo pode constituir um mito, desde que seja suscetível de ser julgado por um discurso. O mito não se define pelo objeto de sua mensagem, mas pela maneira como a profere: o mito tem limites formais, mas não substanciais. ${ }^{2}$

A proposição de Barthes de que o mito é uma fala combina com a constatação feita por Veyne, de certa maneira jocosa, mas realista, de que:

[o]s gregos parecem freqüentemente não ter acreditado muito em seus mitos políticos e eram os primeiros a rir deles quando os expunham cerimoniosamente ... com efeito, o mito tinha-se tornado verdade retórica ... o conteúdo dos discursos de cerimônia não era sentido como verdadeiro e muito menos como falso, mas como verbal. As responsabilidades por esta langue de bois não cabem aos poderes políticos, mas a uma instituição própria desta época, a retórica.

Com efeito, a abordagem do mito deve levar em conta as condições teóricas propostas por Jaeger, Barthes e Veyne. Outro aspecto fundamental que age efetivamente para a manutenção do mito, diríamos sobrevivência do mito, como referência de comportamento da sociedade, é a memória. A memória, um aspecto fundamental para a compreensão da composição e da função do mito, e o aspecto histórico subjacente à construção também devem ser evocados. Segundo Barthes, preocupado com a relação História-mito e História-mitologia,

[é] a História que transforma o real em discurso, é ela e só ela que comanda a vida e a morte da linguagem mítica. Longínqua ou não, a mitologia só pode ter um fundamento histórico, visto que o mito é uma fala escolhida pela História: não poderia de modo algum surgir da "natureza" das coisas. $^{3}$

Aceitando-se a análise de Barthes, tem-se como posto que a palavra, instrumento de transmissão do mito, tem seu significado relacionado com a idéia de preservação, de 
conservação de algum tipo de informação, retenção nos quadros mentais de muito do que foi produzido pela sociedade. Assim, a construção do mito na memória tem, ao mesmo tempo, um caráter social-individual e social-coletivo, já que é o indivíduo que faz o seu registro e a acumula e é o coletivo que a recupera.

A memória é preservada por meio de códigos inteligíveis dentro das sociedades em que é produzida, constituindo assim vestígios do passado vivido por essa mesma sociedade. Para Pierre Nora,

... a memória é vida ... e está em permanente evolução, aberta à dialética da lembrança e do esquecimento, inconsciente de suas deformações sucessivas, vulnerável a todos os usos e manipulações, susceptível de longas latências e de repentinas revitalizações.

Essa breve reflexão sobre mito e memória remete para outra questão fundamental que é o tempo. O tempo da memória não tem uma série contínua e mensurável e sim uma qualidade associativa e emocional. O tempo da memória salta para um ponto desejado e estabelecem-se datas por associações. A consciência de duração é feita pelos seguintes termos: "há muito tempo", "outro dia", ou por associações de experiências vividas pela sociedade ou pelos indivíduos, como, por exemplo, "no tempo de meu avô".

Segundo José Carlos Reis,

[a]pesar de terem sido os criadores da ciência dos homens no tempo, os gregos possuíam também um pensamento extremamente anti-histórico. Concebiam apenas o conhecimento do eterno, do permanente, do imutável, do supralunar. Esse ser supralunar realiza um movimento circular. Aristóteles define o movimento regular por três propriedades: eternidade, unidade e continuidade. A única espécie de movimento a possuir essas características é o circular.

O pensamento grego, segundo Finley, dividiu o tempo da memória, ou seja, o seu passado, em dois tempos: o tempo da era heróica, durante o qual a tradição oral grega foi criada e mantida, tendo como resultado a criação de um passado mítico baseado em elementos que diferiam em caráter e precisão, cuja origem remontava a períodos de tempos bastante esparsos. Essa "tradição" não transmitia meramente o passado, ela o criava. O principal objeto desse período foram a formação e a manutenção de uma identidade grega feita pela criação de uma consciência e de um orgulho pan-helênicos, até mesmo localizados ou de caráter regional, em que emerge a criação do governo aristocrático e especialmente o direito da aristocracia de governar externando a ênfase às suas notáveis qualificações e virtudes. Trata-se de um processo 
de criação mítica que não termina no século VIII a.C., final do chamado "período Homérico" e quando se tem historicamente a formação da polis. Ele continua presente na mitificação de indivíduos combinando elementos antigos com novas formas, adaptando-se às mudanças religiosas e políticas.

A era pós-heróica é marcada pelo interesse na preservação do passado remoto e mítico, todavia totalmente vivo na consciência grega e expressou-se pela conservação e repetição do mapa mítico. O passado heróico era alvo de uma atenção passiva que assegurava a sua manutenção na lembrança social, na versão aceita e perpetua-se nas gerações futuras por meio da preservação desse conhecimento e da sua permanente utilização. Primeiro, o registro desse passado não dispunha de documentos nem arquivos de onde tirá-los, por essa razão foi preservado por meio da oralidade. No segundo momento, da oralidade à prática cultural, incluindo-se aí o registro escrito, tem-se a elaboração do universo ritual que, por si só, fiel às origens da tradição, acaba por consolidar a relação fala-ação que consagra o princípio de que o mito é o principal veículo da memória na sociedade grega.

Pode-se remeter agora para outro aspecto: como os gregos pensavam a relação mito-memória-História? Para Aristóteles, a História preocupa-se com o particular. "Por particular refiro-me ao que Alcibíades fez e pelo que passou”, afirma em Poética. Para o filósofo grego, contrapondo História e Poesia, a Poesia era muito mais filosófica e universal. A principal questão em Aristóteles era distinguir mito de História, pois a atmosfera na qual os primeiros historiadores escreveram, os chamados pais da História, estava impregnada de mitos.

Quando Heródoto atingiu a juventude, o passado distante estava bastante vivo na consciência dos homens, mais vivo do que os séculos ou as gerações recentes: Édipo, Agamenon e Teseu eram mais reais para os atenienses do século $\mathrm{V}$ que qualquer figura histórica anterior a esse século salvo Sólon, e este foi elevado à categoria daqueles, ao ser transformado em figura mítica. ${ }^{4}$

O mito era o grande mestre dos gregos em todas as questões do espírito e de comportamento social. Com ele, aprendiam moralidade e conduta, as virtudes da nobreza, sobre raça, cultura e política. Está aí uma das razões por que a História, na Antigüidade Clássica, em boa parte foi tida com base principalmente na poesia épica, podendo-se comparar então as duas formas de narração do passado. Havia um reconhecimento de que a tradição épica era baseada em fatos concretos, todavia considerem-se as épocas distintas, do ponto de vista da experiência histórico-cultural, e 
é preciso estabelecer a diferença entre Homero e Tucídides, que está justamente na apresentação do estilo de suas escritas. Homero empregou adequadamente a licença poética enquanto Tucídides fez seu relato dos fatos de forma objetiva. No entanto, a fonte de seus escritos é a mesma, a memória coletiva, perpassada pela via da oralidade.

Para os gregos, ser cidadão significa ser membro da polis e participar de suas atividades plenas. A base dessa participação pode resumir-se a dois aspectos essenciais: a aceitação das leis e a ligação ao direito de possuir terras. Assim, só é cidadão quem possui terras e tenha nascido no interior do território da pólis, desde que homem livre ou filho de pais livres. No mundo da polis, há um grande contingente de não-cidadãos, representados principalmente pelos escravos e estrangeiros - metoikoi -, que não têm o direito político. E, por conseqüência, a constituição da cidadania grega é conhecida pela organização e pelo funcionamento da sua unidade básica que é o demos.

Existe nessa constituição uma prática política ligada a aspectos existenciais e a representações que, de certa forma, caracterizam-se como referência da dominação. A retórica é tida como uma dessas representações, na medida em que reproduz fundamentalmente de modo organizado e articulado a filosofia grega. E entenda-se também que toda a educação grega, como elemento institucional de dominação, está alicerçada na formação filosófica. É na ação pedagógica que o mito é utilizado como recurso de retórica para a argumentação e transmissão do pensamento dominante enquanto convencimento e fixação de preceitos históricos, éticos e morais.

Veyne, entretanto, propõe uma indagação: acreditavam os gregos em seus mitos? Reside nessa questão algum tipo de polêmica pouco convencional. Primeiro, Veyne sugere que o mito está contido na tradição e vulgata:

Como é possível acreditar pela metade ou acreditar em coisas contraditórias? As crianças acreditam ao mesmo tempo em que Papai Noel lhes traz brinquedos pela chaminé e esses brinquedos são colocados lá por seus pais; então, acreditam mesmo em Papai Noel? Sim...

Há, por assim dizer, um questionamento a fazer sobre mito e verdade, antes de continuarmos pensando o mito como, ao mesmo tempo, fonte e veículo de informações. Paul Veyne estabelece uma discussão sobre imaginação e verdade pensando no mito como instrumento de comunicação.

Por outro lado, os usos do mito lançam olhares seletivos sobre a verdade e ao longo do tempo, com a transmissão oral ou escrita, seus componentes são comprovados ou não pela prática cultural. Assim, os acontecimentos "míticos" acabam sendo 
superados pelos acontecimentos "históricos", cujas evidências mostram-se racionais em relação ao mito. Deve-se pensar no mito, portanto, enquanto veículo de informações, uma necessidade das verdades encarregadas da manutenção do status quo das poleis gregas e, por analogia, da categoria de cidadãos. A questão não é, pois, “acreditar" nos mitos, mas, sim, entendê-los com seus exemplos e a sua constituição. A função dos mitos na formação do cidadão grego é a de incutir no imaginário da polis a credulidade, a participação e a função de uma pequena parcela da população, parcela essa constituída dos homoioi.

Foram feitas até aqui algumas divagações sobre o papel do mito no comportamento dos segmentos dominantes da cidade grega. É esse o fundamento da construção cultural do mito no mundo mediterrâneo antigo, especialmente com a combinação helenística desembocando no mundo de domínio romano após o século III a.C. O mito, em suas práticas e representações, pode ser trabalhado como comunicação literária, recurso que é dos mais comuns quando se trata de compreender o pensamento de determinados segmentos sociais.

Segundo Hartog,

\begin{abstract}
A tarefa de um historiador da cultura pode, a partir daí, dar a ler estes textos, reconstruindo para falar como a hermenêutica - a questão à qual eles respondem, redesenhando os horizontes de expectativas em que, desde os seus primeiros dias até os nossos ..., eles vieram inscrever-se, recalculando as apostas que assinalaram e significaram, apontando os qüiproqüós que sucessivamente provocaram. Essa historicização não significa modernizá-los ou atualizá-los, mas sobretudo fazer ver sua inatual atualidade: suas respostas a questões que nós não mais levantamos, não sabemos mais levantar ou que simplesmente "esquecemos". 5
\end{abstract}

Para melhor compreender e analisar os aspectos da linguagem literária, veículos dos mitos gregos, deve-se procurar uma teoria lingüística que ofereça subsídios teóricos e práticos para a análise.

O trabalho com o discurso literário significa navegar pela teoria lingüística, mesmo considerando que a tarefa do historiador não tenha por objetivo a análise lingüística. Todavia, é preciso entender o mecanismo da linguagem, a sua estrutura funcional e as várias formas de análise que oferecem elementos observáveis para compreender o momento e a forma em que o discurso foi produzido, o seu alcance na manutenção e afirmação na relação entre opinião pública e o status quo.

Para tanto, propõe-se a utilização da semiótica como instrumento de abordagem teórico-metodológica do mito. Entende-se aqui a semiótica como uma teoria geral de signos $^{6}$ e com esse entendimento abriu-se ainda mais o leque de opções. A aplicação da 
teoria semiótica fundamenta, pois, a análise histórica na medida em que a construção da História também é feita sobre signos. ${ }^{7}$

Quando se trata da leitura de um historiador, as imagens produzidas pelos signos historicizam-se, pois procurar compreendê-las contextualmente é mais do que um hábito, é um compromisso. Quando se chega a esse momento, já estão superados o ceticismo e a ignorância. O leitor avança num logos escolhido, já deu todas as chances ao texto, "[v]isto em seus níveis múltiplos, suas diversas linhas melódicas, suas rupturas também, retomadas, impasses, e como a expressão de uma ou de várias estratégias narrativas". 8

O contato com a relação identidade-alteridade permite encontrar no texto lido toda a sua consistência, sua respiração, e vê-lo animar-se e ser posto em movimento. Semelhanças, vocabulário, cadência, memória, esquecimento, vida, morte, paixões, mitos, antimitos, heróis, anti-heróis são componentes indispensáveis ao texto literário, na medida em que ele representa igualmente, via de regra, a viagem realizada pelo autor. A mescla "do realmente acontecido" com o que "deveria acontecer" ou "teria acontecido" está presente na relação autor-texto quanto ao enredo. No caso de textos produzidos na Antigüidade Clássica, há de se observar que essa viagem acontece quase sempre da epopéia à História, envolvendo figuras heróicas, míticas, lendárias, com defeitos e virtudes humanos, entretanto de traços semidivinizados. Há, por assim dizer, uma narrativa que se coloca à frente do leitor e cabe a ele fazer essa identificação.

A metáfora e a alegoria (alegoria é um conjunto de metáforas) são utilizadas pela linguagem verbal para suprir a ausência de um signo que não transmita, na sua essência, a totalidade de uma qualidade inerente ao signo analisado. Para se entender a metáfora é necessário ter como referência a palavra em uma moldura, ou seja, em seu contexto. Um dos principais veículos da metáfora é o mito, embora a literatura e a poesia sejam também seus grandes meios. No mito, a principal figura de linguagem é a alegoria, que é, nada mais nada menos, uma cadeia de metáfora e simbolismos. Os mitos estão entranhados de alegorias e figuras de linguagem que representam o momento sociocultural de sua produção.

Para entender melhor a alegoria, é necessário retomar um pouco a doutrina benjaminiana. Para Walter Benjamim, ${ }^{9}$ a reabilitação da alegoria é a temporalidade e historicidade do símbolo em oposição à sua eternidade. Para Benjamim, a reabilitação da alegoria será uma reabilitação da História, da temporalidade e da morte na descrição 
da linguagem humana. Além disso, ele condena a redução do símbolo e da alegoria a uma mera redução dos termos a uma relação entre aparência e essência.

Enquanto o símbolo aponta para a eternidade da beleza, a alegoria ressalta a impossibilidade de um sentido eterno e a necessidade de perseverar na temporalidade e na historicidade para construir significações transitórias. Enquanto o símbolo tende à unidade do ser e da palavra, a alegoria insiste na sua não-identidade essencial, porque a linguagem sempre diz outra coisa (allo-agorein), que é aquilo que visava, portanto ela nasce e renasce somente dessa fuga perpétua de um sentido último.

Num contexto determinado, a alegoria pode remeter a uma significação precisa dentre outras; enquanto signo, ela remete a todas as significações possíveis, portanto a nenhuma, não há mais ponto fixo, nem no objeto nem no sujeito da interpretação alegórica que garanta a verdade do conhecimento. A escrita e a alegoria somente são ditas "arbitrárias" para uma posição que mantém a afirmação da possibilidade de um saber necessário, transparente e imediato. Se o sentido da totalidade se perdeu, isso se deve também, e mais ainda, ao fato de sentido e História estarem intimamente ligados.

\section{Uma proposta de análise do mito: Dion Crisóstomo (40-115 d.C.)}

Com o que já foi visto em relação à concepção de mito e uma possível metodologia aplicada para análise, pode-se propor uma análise alegórica dos discursos de Dion Crisóstomo, filósofo grego do II século d.C.

Estudar a obra de Dion Crisóstomo representa um desafio enquanto tarefa para recuperar a realidade histórica, considerando principalmente que se trata de obra literária, revestida e recheada de componentes metafóricos, simbólicos, que expressam sob essa aparência não só a criatividade e a imaginação do autor. Significa também fazer a leitura que possibilite recuperar um momento da História da província do Ponto-Bitínia durante o governo do imperador Trajano (98-117). O período em que a obra foi produzida apresenta, no entanto, importante núcleo documental representado por outras obras literárias, mais direcionadas para a realidade social vivida, e pelas descobertas arqueológicas.

A estrutura urbana no mundo greco-oriental, localizado na Ásia Menor e na Síria, mantém as mesmas bases sobre as quais foi montada. A presença romana não modificou o perfil das cidades, as quais apresentam uma tradição milenar de culturas 
orientais que não se alteraram com a chegada das instituições municipais dos romanos. Ao contrário. O que se vê é o fortalecimento das condições sem nenhuma modificação das monarquias orientais.

A combinação histórica mais marcante na definição do modo de vida das províncias orientais foi o largo emprego da língua grega e a preservação das estruturas mentais do Oriente. A chegada dos romanos não provoca mudanças estruturais. Ao contrário, adotando a prática do respeito às condições históricas das províncias integradas ao seu imenso corpo de conquistas, Roma buscou preservar as raízes provinciais como mecanismo de dominação. É o que ocorreu no Ponto-Bitínia, que teve assim o desenvolvimento das suas cidades no interior da dominação romana conservando as suas bases greco-orientais. Para manter relações regulares, Roma serviuse de uma política diplomática que quase sempre se valeu das chamadas "forças vivas" locais, tidas como formadoras de opinião e capazes de assegurar a presença romana, possivelmente sem grandes traumas. A estratégia mais evidente era a utilização sistemática e ordenada dos meios de comunicação entre Roma e as províncias. Neste caso, o mar Mediterrâneo teve papel destacado, tornando-se, desde o século I a.C., o mare nostrum dos romanos. Por meio dele, alcançavam-se regiões as mais distantes, utilizando-se vias complementares como o rio Nilo no Egito, o mar Egeu entre a Grécia e a Ásia Menor, a Propôntida na entrada do mar Negro, e o próprio mar Negro. Esses caminhos, que eram os caminhos da vida econômica do Império romano, levavam também aspectos das culturas ocidental e oriental. O Mediterrâneo era, pois, um grande espaço cultural,

que se constituiu como área privilegiada de elaboração e circulação de idéias, não se resume nem geográfica nem culturalmente a uma massa aquática e à zona terrestre limitadas pelas margens de um mar interior que se confina com a Europa e a África e, no extremo oriental, com a Ásia. É um espaço global mais vasto - marítimo, ribeirinho e continental, definido culturalmente a partir de um núcleo geográfico ...

É certo que as cidades bitinianas enfrentavam problemas políticos internos, os quais podem ser bem apreendidos no Livro $\mathrm{X}$, que contém as Cartas trocadas entre Plínio, o Jovem, e Trajano. Os problemas vinham ocorrendo desde o governo de Vespasiano (69-79 d.C.), o que se pode observar pelas obras de Tácito, e arrastaram-se até Trajano, encontrando seu epiceno na época de Domiciano (81-96 d.C.). Tais problemas consistiam, principalmente, em atritos entre as cidades que disputavam a hegemonia regional, a adoção, da parte de alguns imperadores, de uma 
política de perseguições que atingiu intelectuais e filósofos, principalmente os de origem grega, como é o caso de Dion Crisóstomo.

Os Discursos de Dion Crisóstomo são compostos de vários temas. Mas há neles um tema dominante, uma tônica: despertar os cidadãos para o sentido da liberdade e da paz de que gozavam as cidades, sendo, contudo, impossível voltar ao passado glorioso, incomparável sob todos os aspectos. Dion Crisóstomo dava conselhos para que a vida pública não sofresse os efeitos das convulsões sociais, prejudiciais ao bom funcionamento das cidades. Não é por acaso que Dion Crisóstomo, originário de família aristocrática, se pusesse a fazer construções que doava à cidade de Prusa.

Dos chamados cínicos há na cidade um grande número ... Nas encruzilhadas, nas ruelas e nos pórticos dos templos, congregam e enganam os escravos, os marinheiros e as pessoas dessa ordem, dando livre curso a suas falácias, a sua conversa inesgotável e suas respostas vulgares. Com isso, nada fazem de bom, senão danos muito graves. ${ }^{10}$

A divulgação das idéias cínicas tinha a conotação de propaganda política, que situava frente a frente a realeza, como obra dos deuses, e a tirania. Essa oposição, de natureza filosófica, provocou a perseguição aos filósofos e aos senadores contrários a Vespasiano e a Domiciano.

Dion Crisóstomo pronunciou seus Discursos em várias cidades do Oriente na época de Trajano, especialmente em Alexandria e em Társia, além dos discursos bitinianos pronunciados aos cidadãos de Prusa, de Nicéia e de Nicomédia. Como nos atesta John Cohoon,

Ao longo dessa peregrinação, ele alcançou Borístenes, florescente colônia de Mileto ao norte do Mar Negro e não distante da moderna Odessa. Ele penetrou também em Viminacium, campo romano permanente no Danúbio, e viveu entre os selvagens Getas, cuja História ele escreveu. ${ }^{11}$

Após a morte de Domiciano, em 96, o exílio de Dion Crisóstomo terminou. Antes de retornar a Roma, no verão do ano de 97, fez um discurso durante a realização da assembléia dos gregos em Olímpia. Uma vez em Roma, foi recebido pelo vetus imperador Nerva (Discurso XVIII). O contato com o princeps possibilitou a Dion Crisóstomo reivindicar benefícios aos habitantes de Prusa,

...mas foi impedido pela doença [de Nerva] de alcançar pleno sucesso. Ele retornou, contudo, a Prusa com a notícia de que tais favores estavam garantidos e então encabeçou uma embaixada enviada pelos cidadãos para exprimir seus agradecimentos ao Imperador. Essa embaixada, entretanto, encontrou Nerva morto e Trajano Imperador em seu lugar" ${ }^{\prime 2}$.

O contato com o imperador Trajano, em 98 ou 99, deu a Dion Crisóstomo nova oportunidade de estreitar ligações com o princeps, tal como ocorrera com Nerva. Antes 
de Trajano partir para a campanha da Dácia, recebeu do imperador os favores reivindicados para Prusa. Depois disso, de Roma, Dion Crisóstomo viajou para Alexandria e outras localidades do Oriente, voltando depois para sua cidade natal, já no final do ano 99 ou início do ano 100.

Em Prusa, Dion Crisóstomo, por conta própria, cuidou de urbanizar sua cidade oferecendo-lhe melhorias que lhe custaram dinheiro e aborrecimentos pessoais. Para dar conta dessas melhorias, foram demolidas algumas construções da cidade, o que lhe custou um processo. Plínio, o Jovem, que foi legatus pro praetore do Ponto-Bitínia nos anos 111-112, interveio junto ao princeps Trajano, conforme a relata na Carta X.81: "Dion Cocceianus, ao que parece, quis, numa reunião da boule, que um edifício público, que foi erigido às suas custas, fosse transmitido formalmente à cidade".

Uma das razões do desejo de Dion Crisóstomo, possivelmente a mais forte, conforme Plínio, o Jovem, é que “... havia no mesmo monumento a estátua e os corpos inumados [da mulher de Dion e de seu filho] ... ${ }^{13,}$

Graças ao seu nascimento e por ser homem rico e de posição política destacada, Dion Crisóstomo teve ótimo relacionamento com seus compatriotas de Prusa. Como aristocrata, ele precisava de sua comunidade. As honras formais e informais oferecidas pelos concidadãos - o aplauso, as magistraturas, as estátuas, os santuários, os jogos funerários - constituíam o prêmio material e espiritual dos aristocratas, os quais retribuíam por meio de presentes na forma de liturgias cívicas e do exercício de influência política em favor de sua terra natal. Essa simbiose socio-política é revelada por Dion Crisóstomo quando ele se vangloria dos benefícios concedidos à cidade de Prusa.

Por outro lado, Dion Crisóstomo registra a rivalidade entre as cidades bitinianas; entre Nicéia e Nicomédia, e entre Prusa e Apaméia. Essas rivalidades fazem que Prusa receba tratamento especial de Dion Crisóstomo por meio da construção de imagens generosas da cidade, a ponto de elevá-la ao nível de líder das cidades e cabeça de uma federação, mesmo afirmando que:

Vocês podem estar seguros de que, embora Prusa não seja a maior das nossas cidades e não tem sido calma por longo tempo, ela é mais ilustre do que muitas igualmente estimada do outro lado do mundo, e que ela tem motivado por muito tempo seus cidadãos a colocá-la no topo, não em último, ou em terceiro ou em segundo, na competição com todas as outras cidades gregas. ${ }^{14}$ 
Dion comenta ainda que Prusa era uma cidade cheia de cabanas e casebres e esse quadro serviu de forte incentivo às suas atitudes evergéticas. Dion Crisóstomo morreu, ao que parece, por volta do ano 120 .

\section{A concepção teogônica em Dion Crisóstomo: o Discurso Olímpico}

O Discurso Olímpico foi lido por Dion Crisóstomo em Olímpia no ano 97 d.C., diante de uma grande platéia que foi à cidade para assistir aos jogos e diante da famosa estátua de Zeus que foi esculpida por Fídias, o grande escultor grego, mais de cinco séculos antes.

Em seus comentários introdutórios, Dion Crisóstomo nos conta que estava retornando do Danúbio, onde o exército romano sob o comando de Trajano estava iniciando a Segunda Guerra Dácica, e lança a questão: deveria falar aos ouvintes sobre a terra dos dácios e o impedimento da guerra ou abordar o tema sugerido pelo deus em cuja presença eles estão? Para tanto, descreve algumas passagens vivenciadas junto ao exército romano:

\footnotetext{
Eu, que era desnecessário a todas àquelas coisas [legiões, armamentos], aproximei-me entre os homens que não eram broncos, e não tinham tempo para ouvir os discursos, mas estavam muito sensíveis e tensos como cavalos de corridas na linha de partida, ansiosos pela largada e em seu excitamento e avidez pisoteando o solo com seus cascos. Nesse lugar podíamos ver por toda parte espadas, por toda parte corseletes, por toda parte lanças, e todo o lugar estava repleto de cavalos de armas, e com homens armados. ${ }^{15}$
}

Dion Crisóstomo não vacila em falar do presente em termos claros nos discursos dirigidos aos seus ouvintes gregos. A anedota histórica situada no passado não é para Dion Crisóstomo um lugar de fuga do presente, no máximo um lugar de reconhecimento que permite estabelecer um vai e vem entre o presente vivido a que Dion Crisóstomo assiste lucidamente e o passado prestigioso então pano de fundo da vida real. Ele respeita e protege as recordações de um passado que conhece bem, mas se recusa a refugiar-se, mesmo em pensamento, como tantos gregos de seu tempo, neste brilho de outrora ou que sua cultura lhe faz viver, se recusa como muitos a forjar estas suas recordações prestigiosas como armas contra Roma. Condena os falsos filósofos e os perigosos sofistas que pregam a revolta contra Roma pela exaltação do passado glorioso. ${ }^{16}$ 
Dion Crisóstomo busca a reconciliação geral e procura no passado exemplos de acordos, os modelos de virtudes cívicas que propõe como ideal para os seus contemporâneos. Garantidas pela autoridade dos anciãos, estas qualidades parecem necessariamente ser eternas e consubstanciais para a cultura grega. É por este fasor que ele propõe o tema da Guerra Dácica. Embora os gregos se encontrem, naquele momento, diante de um lugar permeado de sentimentos religiosos e helenísticos, o mundo ao seu redor é retomado com a descrição de um campo de batalha muito próximo. Dion Crisóstomo lembra aos seus ouvintes que há uma campanha militar não muito longe e que faz parte desse mundo vivido.

Completamente sozinho eu me mostrei no meio deste poderoso anfitrião, perfeitamente tranqüilo e o mais sereno observador da guerra, fraco no corpo e avançado nos anos, não conduzindo 'um cetro dourado' ou sagrados adornos de ouro ... desejando ver homens fortes lutando por império e poder, e seus oponentes por liberdade e terra nativa. Então, não porque eu me acovardei diante do perigo ... mas porque eu retomei à memória um velho juramento, eu mudei meu curso para junto de vocês, sempre considerando que as coisas divinas tem o clamor maior e mais vantajoso do que as coisas humanas, por mais importante que estas posam ser. ${ }^{17}$

É digno de nota que Dion Crisóstomo, na referência à Guerra Dácica não faz referência ao nome do imperador, fala apenas em "homens fortes lutando por império e poder". Essa é uma característica presente em todas as referências que ele faz a Nerva ou a Trajano. As nomeações dos imperadores contemporâneos são sempre feitas por analogias.

Os personagens que animam as estórias contadas por Dion Crisóstomo são sempre os mesmos e são poucos: são os filósofos Sócrates, Diógenes, Pitágoras; os heróis de mitologia popular Hércules, de caráter polêmico, Ciro, Crésus, os sete sábios, Sólon e o herói por excelência da história grega neste momento, aquele cujo império prefigurou a conquista romana, Alexandre, o Grande. Esses personagens intervêm freqüentemente nos discursos de Dion Crisóstomo. Pôr em cena um soberano (Alexandre) e um filósofo (Diógenes), ou novamente um rei velho (Filipe) e um príncipe jovem (Alexandre) seria um processo crítico. Por meio da utilização das figuras existentes e presentes no imaginário grego, Dion Crisóstomo faz referência direta, aproximando-se da realidade do período vivido por ele, principalmente em relação aos governos de Nerva e de Trajano. Podemos ver nessas referências a evocação das figuras dos imperadores romanos de seu período que estão no presente, mas que têm a justificativa de seu papel político no passado memorável dos gregos por intermédio das figuras helenísticas que representam a unificação do mundo universal. 
Retóricos e filósofos criticaram ou condenaram Alexandre; mas, se fosse maltratado como herói retórico, Alexandre também era, desde o reinado de Augusto e como criador do império, o marco de um debate ideológico sério. Alexandre seria capaz de derrotar Roma se ele tivesse que enfrentar a sua força? A idéia de uma possível vitória deste grande conquistador havia sem dúvida confortado os gregos que acharam difícil aceitar a lei do vencedor.

Embora seja apenas inicial essa preocupação de Dion Crisóstomo no Discurso Olímpico, a mera menção da dúvida sobre o tema é pura figura de retórica para relembrar aos gregos que o mundo romano ainda está presente, embora a preocupação com sua grecidade, representada na concepção divina e suas imagens, seja a que fundamente o seu ethos.

Dion Crisóstomo finalmente escolhe a segunda opção e, após explicar que a concepção da natureza dos deuses, e especialmente dos mais importantes, é inata em toda a humanidade, e que esta inata concepção e crença é fortalecida pelas experiências dos homens e na observação do seu mundo, dá uma classificação do modo em que a concepção e a crença na sua existência são implantadas na mente dos homens. No parágrafo 39 ele faz uma classificação sobre a noção inata e a noção adquirida. Então na seção 44 e seguintes ele subdivide a noção adquirida em voluntária e de exortação dada pelos poetas, a compulsória e prescritiva dada pelos legisladores, aquela dada pelos pintores e escultores e as noções e conceitos como as demonstradas e expostas pelos filósofos. Dion Crisóstomo é cuidadoso, contudo, em apontar que os poetas, legisladores, escultores e outros não teriam influência se não fosse a noção primária e inata.

Da crença dos homens nas divindades e a suposição de que haja um deus que nós preservamos e cuja origem ... foi a idéia que é inata em toda a humanidade e veio resultar em fatos reais e verídicos, uma idéia que não foi estruturada desordenadamente nem ao acaso, mas tem sido poderosa e duradoura desde o início dos tempos, e tem surgido entre todas as nações, sendo um dom comum e geral aos seres racionais. Como uma segunda fonte de informação nós designamos a idéia que tem sido adquirida e de fato implantada na alma dos homens por meio das narrativas contadas, mitos, e costumes, em alguns casos não atribuídas a um autor ou anônimas, mas em outros casos escritos e tendo como seus autores homens de grande fama. Desta noção adquirida dos seres divinos deixe-nos dizer que uma parte é voluntária e passível de exortação, uma outra parte compulsória e prescritiva. ... Mas qual destas duas influências mencionadas deve ser chamada ao tempo primitivo, entre nós gregos, nominativamente, poeticamente ou legislativamente, eu tenho receio em não poder discutir isso detalhadamente na presente ocasião; mas talvez seja conveniente que o tipo das quais dependem, não de penalidades, mas de persuasão deveria ser mais antiga do que o tipo que aplicam compulsão e prescrição. Após este ponto ... o sentimento da raça humana sobre o seu primeiro e imortal ancestral, aquele a quem nós temos na herança da Hélade chamado de Zeus Ancestral, caminha passo a passo junto com aqueles homens que têm seguido seus mortais e humanos ancestrais. 
Nessa citação podemos analisar alguns pontos que levam a uma relação com a parte introdutória do discurso como "a noção inata e a noção adquirida e implantada na alma dos homens". Esta comparação é clara em relação à formação do sentimento religioso e de toda a concepção teogônica entre os gregos e os "bárbaros", como se refere Dion Crisóstomo em várias passagens. A relação entre a naturalidade do culto ao Zeus Ancestral desenvolvido pelos gregos e a imposição ao culto do imperador imposto pelos romanos. O caráter da ancestralidade hereditária para a formação de uma população que se identifica como descendente do deus fundador de toda a humanidade e em cujo templo eles se encontram.

\footnotetext{
Na verdade a benevolência e desejo de servir que a prole sente perante seus ancestrais está, no primeiro tipo, presente neles, inato, como um presente da natureza e como um resultado dos atos de bondade recebida, desde que isto tenha sido gerado imediatamente do nascimento do amor e apreço em retribuição ... que o iniciou e o nutriu e o amou ...

Considerando o segundo e o terceiro tipo, que são derivados de nossos poetas e legisladores, o formador exorta-nos a não conter nossa gratidão daquele que é o mais antigo e do mesmo sangue, além de ser o autor da vida e da existência, o mais antigo usando a compulsão e o tratamento da punição àqueles que refutam obediência ...
}

Após essas idéias, o orador procede para o que é mais importante no discurso no qual ele oferece uma grandeza de idéias aparentemente originais sobre quais são o campo e a função das artes plásticas e quais são as suas limitações. Ele coloca os seus pensamentos na boca de Fídias, que analisa o específico caso de sua própria estátua de Zeus e atenta para mostrar que ele usou todos os recursos da arte da escultura na produção da ilustre estátua do mais importante dos deuses. Fídias, no curso de sua exposição, fala sobre outras coisas que ele usou na sua concepção de Zeus de Homero, faz também uma detalhada comparação entre a respectiva capacidade da poesia e da escultura em retratar e representar e decide sobre a vantagem da poesia.

Nenhum escritor antigo até o tempo de Dion Crisóstomo, cujo trabalho tenha sobrevivido, segundo J. W. Cohoon ${ }^{18}$, nos deu tal tratamento sobre o tema. Os outros, assim como Plutarco, fizeram apenas passagens de referências às artes plásticas. Certamente nenhum deles fez uma comparação tão detalhada entre a escultura e a poesia. Em Flávio Josefo, ainda segundo Cohoon, pode-se encontrar um tratamento sobre o tema. Paul Hagen, ${ }^{19}$ contudo, em suas Quaestiones Dioneae, tenta mostrar uma comparação entre certas passagens de Cícero, Plínio, o Velho, e Quintiliano que Dion Crisóstomo não é original em suas teorias de arte, mas assumiu a concepção de Pérgamo, onde estava a mais famosa escola de escultura que florescia em seu tempo. O 
trabalho mais exemplar conhecido dessa escola é o Gaulês Agonizante, que agora está no Museu Capitolino em Roma.

Dion Crisóstomo certamente tinha acesso fácil a Pérgamo. Se ele não é original em suas idéias sobre a arte, ele estava muito interessado nela, de qualquer forma. A questão da originalidade das idéias não é o importante para o historiador. A representação social que está contida em seu discurso supera qualquer tentativa de abordagem sobre a originalidade ou influência de Dion Crisóstomo sobre os pensadores de seu tempo. Segundo Cohoon, Dion Crisóstomo abordou esse tema em mais de uma ocasião e traçou de diferentes maneiras a abordagem das artes plásticas em diferentes lugares para diferentes platéias até encontrarmos a versão que hoje temos nesse discurso.

O livro organizado por Simon Swain, ${ }^{20}$ uma coletânea de textos produzidos por estudiosos sobre Dion Crisóstomo, tem mostrado os caminhos abertos para as novas pesquisas sobre o autor bitiniano. São poucos os historiadores que analisam a documentação de Dion Crisóstomo. O maior interesse tem sido nas áreas de filosofia e de literatura. Em 2001, a autora defendeu junto ao Programa de Pós-Graduação, nível de Doutorado, da Universidade Estadual Paulista "Júlio de Mesquita Filho", campus de Assis, a tese sob o título "Princeps e Basileus nos Discursos de Dion Crisóstomo (96 a 117 d.C.)", sob a orientação do Dr. Ivan Esperança Rocha. Esse foi um trabalho de iniciação à documentação de Dion Crisóstomo no que tange à produção brasileira, quiçá até mesmo em língua portuguesa. Os pesquisadores Christopher P. Jones, ${ }^{21}$ Tim Whitmarsh, Simon Swain, ${ }^{22}$ Aldo Brancacci, ${ }^{23}$ Paolo Desideri ${ }^{24}$ e John Moles ${ }^{25}$ não se cansam de externar que a documentação é instigante e apaixonante, mas, no entanto, pela sua característica retórica e alegórica, muito difícil de ser analisada. Ao se propor este artigo, pretende-se apenas debater algumas possibilidades metodológicas de abordagem da documentação em questão que se destaca, principalmente, por sua constituição documental que desafia o historiador, mas que, no entanto, encontra várias possibilidades nas discussões interdisciplinares atuais presentes na historiografia atual.

ROSSI, Andrea Lúcia Dorini de Oliveira Carvalho. Mythology: Methodological Approach for the Classic Antiquity Historian. História, São Paulo, v. 26, n. 1 p 36-52, 2007.

Abstract: The central theme of this article is the application of the semiotical analysis as methodology of historical analysis of the mith present in the Dio 
Chrysostom's Discourses, Bitinian philosopher who lived between 40 and 115 A.D in Roman Empire.

Keywords: Mith, Roman Empire, Dio Chrysostom

Artigo recebido em 04/2007. Aprovado em 06/2007.

\section{NOTAS}

\footnotetext{
* Professora do Departamento de História - Faculdade de Ciências e Letras de Assis - Unesp - 19806900 - Assis/SP. E-mail: adrossi@tvcassis.com.br

${ }^{1}$ ELIADE, Mircea. Mito e Realidade. Trad. Pola Civelli. São Paulo: Ed. Perspectiva, 1989. p.11.

2 BARTHES, Roland. Mitologias. Trad. Rita Buongermino e Pedro de Souza. 10. ed. Rio de Janeiro: Bertrand Brasil, 1999. p.131.

${ }^{3}$ BARTHES, Roland. Op. cit., p.132.

${ }^{4}$ HARTOG, François. O Espelho de Heródoto. Trad. Jacyntho Lins Brandão. Belo Horizonte: Ed. UFMG, 1999. p.34.

${ }^{5}$ HARTOG, François. Op. cit., p.15-16.

${ }^{6}$ Entendendo como signos toda e qualquer coisa que substitua ou represente outra organizada sob a forma de linguagem, verbal ou não-verbal.

${ }^{7}$ Vamos entender signo também como sinal, vestígios, indícios. O historiador trabalha com todo elemento que pode representar determinado momento social, num determinado tempo e espaço.

${ }^{8}$ HARTOG, François. Op. cit., p.17.

${ }^{9}$ GAGNEBIN, Jeanne Marie. História e Narração em Walter Benjamin. São Paulo: Perspectiva, 1994. p.86.

${ }^{10}$ CHRYSOSTOM, Dion. Orations. Trad. J.H. Cohoon. Cambridge/London: Harvard University Press/William Heinemann, 1971. v.I, p.XXXII.9.

${ }^{11}$ Idem, p.IX.

12 Idem, p.X-XI.

${ }^{13}$ Idem, p.X.81.2.

${ }^{14}$ Idem, p.XLIV.9.

${ }^{15}$ Idem, p.XII, 19.

${ }^{16}$ Idem, p.XXXII, 62.

${ }^{17}$ Idem, p.XII, 19-20.

${ }^{18}$ Idem.

${ }^{19}$ HAGEN, Paul. Quaestiones Dioneae. H. Fiencke, Ex officina, 1887.

20 SWAIN, S. (ed.). Dio Chrysostom: politics, letters, and philosophy. Oxford: Oxford University Press, 2000.

${ }^{21}$ JONES, C. P. The Roman world of Dio Chrysostom. Cambridge MA, 1978.

${ }^{22}$ SWAIN, S. Op. cit.

${ }^{23}$ BRANCACCI, A. Rhetorike philosophousa: Dione Crisostomo nella cultura antica e bizantina. Naples, 1986.

${ }^{24}$ DESIDERI, P. Dione di Prusa: un intelletuale greco nell' impero Romano. Messina, 1978.

${ }^{25}$ MOLES, J. L. 'The career and conversion of Dio Chrysostom', JHS, 98, 1978, 79-100.
} 